\title{
PENGEMBANGAN MEDIA KOMUNIKASI PEMASARAN BERBASIS WEBSITE PRODUK TEACHING FACTORY DI SMKN 1 CIBADAK
}

\author{
Development of Marketing Communication Media Based on Website \\ Teaching Factory Products at SMKN 1 Cibadak
}

\author{
Dewi Indah Larasati*, Yatti Sugiarti, Shinta Maharani \\ Program Studi Pendidikan Teknologi Agroindustri, Universitas Pendidikan Indonesia \\ *dewiindah.larasati@student.upi.edu
}

\begin{abstract}
ABSTRAK
SMKN 1 Cibadak merupakan salah satu sekolah menengah kejuruan yang menerapkan pembelajaran teaching factory dengan membangun empat miniatur industri. Hasil produk teaching factory yang dihasilkan siswa memiliki jangkauan pasar dengan media komunikasi yang terbatas, sehingga diperlukan media komunikasi pemasaran berbasis website. Website merupakan salah satu media pemasaran yang dapat digunakan untuk memasarkan produk dan memberikan informasi menarik dengan berupa teks foto dan video mengenai produk teaching factory. Media komunikasi pemasaran berbasis website dikembangkan menggunakan aplikasi system pendukung seperti PHP (Personal Home Halaman) dan MySQL. Tujuan penelitian ini adalah: (1) Mengetahui tahapan pengembangan media pemasaran berbasis website jual beli produk teaching factory menggunakan PHP Apache MySQL, (2) Mengetahui kelayakan pengembangan media pemasaran teaching factory berbasis website, (3) Mengetahui respon pengguna terhadap media pemasaran teaching factory berbasis website jual beli produk teaching factory di SMKN 1 Cibadak. Pengembangan media pembelajaran ini menggunakan metode waterfall, tahapannya meliputi Requirement Analysist, System Design, Implementation, Integration and Testing, Deployment of System. Hasil penelitian ini menunjukan media komunikasi pemasaran berbasis website dinyatakan 'Sangat Layak" oleh ahli media, dinyatakan "Layak" oleh ahli pemasaran, serta dinyatakan "Sangat Layak" berdasarkan respon pengguna media komunikasi pemasran. Secara keseluruhan dapat disimpulkan bahwa media komunikasi pemsaran berbasis website untuk produk teaching factory layak untuk digunakan pada kegiatan marketing promotion.
\end{abstract}

Kata kunci: Media komunikasi pemasaran, teaching factory, website

\begin{abstract}
SMKN 1 Cibadak is one of the vocational high schools that applies teaching factory learning by building four industrial miniatures. The result of teaching factory products produced by students has a limited market reach with communication media. Website-based marketing communication media is one of the marketing media that can be used to market products and provide interesting information in the form of text, photos and videos about teaching factory products. Website-based marketing communication media are developed using supporting system applications such as PHP (Personal Home Halaman) and MySQL. The objectives of this study are: (1) Knowing the development stages of marketing media based on website buying and selling teaching factory products using PHP Apache MySQL, (2) Knowing the feasibility of developing marketing media for teaching factory based websites, (3) Knowing user responses to teaching marketing media factory based website buying and selling teaching factory products at SMKN 1 Cibadak. The development of this learning media uses the waterfall method, the stages include Requirement Analyzer, System Design, Implementation, Integration and Testing, Deployment of System. The results of this research show that web-based marketing communication media are declared "Very Appropriate" by media experts, declared "Feasible" by marketing experts, and declared "Very Appropriate" based on user responses of marketing communication media users. Overall, it can be concluded that the website-based marketing communication media for teaching factory products are feasible to be used in marketing promotion activities
\end{abstract}

Keywords: Marketing comunication media, teaching factory, website 


\section{PENDAHULUAN}

Teaching factory merupakan konsep pembelajaran di SMK berbasis produksi yang mengacu pada standar produksi yang berlaku di industri, serta dilaksanakan dalam suasana seperti pada industri. Merujuk pada pernyataan Direkotarat Pembina SMK (2017), teaching factory diharapkan dapat menjadi wahana kreativitas pengembangan entrepreneurship (kewirausahaan) siswa di sekolah. Hal ini sejalan dengan tujuan khusus SMK yang tertera pada UU No. 20/2003 Penjelasan Pasal 15 poin (f), yakni menyiapkan siswa supaya dapat bekerja mandiri atau mengisi lowongan pekerjaan yang telah ada. Sekolah yang mengimplementasikan teaching factory harus mengacu pada standar tersebut sebagai dasar penyusunan program pembelajaran yang akan digunakan. Pada salah satu parameter implementasi teaching factory terdapat sub parameter marketing promosi yang berkaitan dengan kejelasan target, segmen, dan jangkauan pasar serta penyesuaian metode dan pelaku kegiatan promosi (Direkotarat Pembina SMK, 2015).

SMKN 1 Cibadak merupakan salah satu SMK yang menerapkan model pembelajaran teaching factory dengan membangun empat miniatur industri, yakni Minuman sari buah lemon, bakery, yoghurt, dan bakpia ubi ungu. Berdasarkan pelaksanaan model pembelajaran teaching factory di SMKN 1 Cibadak sudah sesuai dengan tujuh parameter baku implementasi teaching factory yang diterapkan oleh Dikrektorat PSMK tahun 2017.

Parameter-parameter yang perlu disesuaikan kembali adalah peningkatan hubungan kerja sama dengan industri, kegiatan manajemen secara berkala, serta kegiatan marketing promosi. Kegiatan marketing-promosi produk teaching factory yang dihasilkan siswa memiliki jangkauan pasar yang terbatas, hanya di lingkungan internal sekolah, dan media komunikasi pemasaran yang digunakan terbatas hanya melalui media sosial facebook sekolah, sehingga tidak adanya media komunikasi pemasaran resmi untuk menjangkau pasar yang lebih luas guna mempromosikan produk teaching factory yang telah dihasilkan.

Untuk memiliki jangkauan pasar yang luas dibutuhkan adanya proses pemasaran melalui internet. Hal yang membedakan pemasaran melalui media internet dengan menggunakan website dengan pemasaran secara konvensional yaitu proses pemasaran lebih cepat dengan biaya yang lebih murah. Website juga menawarkan sejumlah informasi relatif lebih banyak dibanding media lain. Informasi yang bersifat publik menjadi efektif dan efisien bila disebarkan melalui website (Istanto,2001). Keuntungan menggunakan website sebagai media komunikasi pemasaran antara lain website merupakan media informasi dengan cakupan yang luas. Website juga mudah diakses oleh publik, sehingga mempermudah untuk membangun hubungan baik dengan publik dan industri dan dengan penggunaan website juga dapat mengangkat citra lembaga sekolah.

Pembuatan website sebagi media komunikasi pemasaran produk teaching factory di SMKN 1 Cibadak menggunakan aplikasi sistem pendukung seperti PHP dan MySQL. PHP digunakan untuk membuat tampilan website menjadi lebih dinamis, sehingga maintenance situs website tersebut akan lebih mudah dan efisien karena untuk merubah satu data pada website tidak harus mengubah kode yang menyusun halaman website (Mukaromah \& Rosadi, 2015). Menurut Fauzi (2013) SQL (Structure Query Language) adalah suatu bahasa yang digunakan untuk mengakses database relasonal. MySQL ini mendukung untuk membuat database, menciptakan tabel, menambah data, dan mengambil data yang berada dalam database. Tujuan dari penelitian ini adalah untuk mengetahui tahapan dan tingkat kelayakan media komunikasi pemasaran berbasis website dalam proses jual beli produk teaching factory di SMKN 1 Cibadak.

\section{METODE}

Metode penelitian yang digunakan untuk membuat produk media pemasaran berbasis website adalah metode Waterfall (Aryadhi,2015) yang meliputi (1) analisis persyaratan yaitu tahap awal dimana dilakukan analisis dari kebutuhan yang diperlukan seperti perangkat keras, perangkat lunak dan informasi konten website; (2) Desain sistem yaitu proses perancangan struktur produk menggunakan storyboard; (3) Implementasi yaitu penerapan storyboard yang telah dirancang menjadi unit program menggunakan aplikasi personal home page (php), apache, dan MySqL, yang kemudian dilakukan pengujian subprogram dengan blackbox; (4) Integrasi dan Pengujian yaitu tahap 
uji coba kesiapan website yang telah diintegrasikan dalam bentuk url atau alamat website oleh ahli media dan ahli pemasaran sebagai expert judgment atau validator; (5) Penyebaran sistem yaitu tahapan penyebaran produk yang akan di uji cobakan oleh responden; (6) Perawatan yaitu tahap perbaikan website apabila ditemukan hal-hal yang dirasa perlu diperbaiki.

Partisipan pada penelitian ini subyek yang terlibat diantaranya adalah peneliti, pihak sekolah yang terdiri dari Ketua bidang teaching factory dan penanggung jawab pemasaran teaching factory, dan siswa SMKN 1 Cibadak yang melaksanakan teaching factor. Populasi dalam penelitian ini pengguna smartphone yang dapat terkoneksi jaringan internet untuk mengakses media komunikasi pemasaran berbasis website teaching factory. Teknik pengambilan sampel dalam hal ini menggunakan teknik purposive sampling (pertimbangan tertentu). Pemilihan sampel dalam penelitian ini harus memenuhi kriteria pengguna aktif internet dan pernah melakukan perbelanjaan secara online. Media komunikasi pemasaran yang dibuat diuji cobakan pada sembilan puluh tujuh orang responden dengan MoE sebesar 10\% dan derajat keyakinan 95\% untuk mengetahui jumlah sampel responden yang diperlukan.

Penelitian ini menggunakan tiga buah instrumen. Pertama, instrumen pengujian balckbox yang ditujukan untuk peneliti sebagai pembuat program agar mengetahui fungsionalitas struktur program. Kedua, instrumen lembar validasi media pemasaran untuk ahli media dan ahli pemasaran. Ketiga, instrumen angket atau kuesioner yang ditujuan untuk responden sebagai tanggapan kebermanfaatan website yang dikembangkan.

Kelayakan didasarkan pada tanggapan responden mengenai media komunikasi berbasis website sebagai media pemasaran produk teaching factory di SMKN 1 Cibadak yang diambil melalui kuesioner. Respon yang diberikan responden akan dikonversi kedalam skor skala 1-4 (Skala Likert). Dalam skala ini, jawaban tiap item instrumen mempunyai gradasi dari sangat tidak setuju sampai sangat setuju (Sugiyono, 2011).

Tabel 1. Skala Likert

\begin{tabular}{|c|l|}
\hline Nilai & \multicolumn{1}{|c|}{ Kriteria } \\
\hline 1 & Sangat Tidak Setuju (STS) \\
\hline 2 & Tidak Setuju (TS) \\
\hline 3 & Setuju (S) \\
\hline 4 & Sangat Setuju (SS) \\
\hline
\end{tabular}

Hasil data dari lembar validasi yang dilakukan oleh para ahli kemudian dianalisis untuk diketahui tingkat kelayakanannya. Teknik analisis data yang sesuai untuk menganalisis hasil angket adalah teknik analisis deskriptif dengan rata-rata skoring jawaban pada masing-masing item yang dinilai (Sugiyono, 2011). Rumus yang digunakan sebagai berikut :

$$
\text { Presentase }(\%)=\frac{\text { Nilai yang diperoleh }}{\text { Nilai maksimum }} x 100
$$

Hasil rata-rata interpretasi skor yang didapatkan kemudian dikonversikan sehingga diperoleh hasil kelayakan produk. Tabel konversi tingkat kelayakan kuisioner validasi ahli dapat dilihat pada Tabel 2 berikut:

Tabel 2. Interpretasi Kelayakan Media Pemasaran Website Teaching Factory

\begin{tabular}{|c|l|c|l|}
\hline Skala & \multicolumn{1}{|c|}{ Persentase } & Kualifikasi & \multicolumn{1}{|c|}{ Konversi } \\
\hline 1 & $25 \%<x \leq 43,75 \%$ & $\begin{array}{c}\text { Sangat Tidak } \\
\text { Setuju }\end{array}$ & Sangat Tidak Layak \\
\hline 2 & $43,75 \%<x \leq 62,5 \%$ & Tidak Setuju & Tidak Layak \\
\hline 3 & $62,5 \%<x \leq 81,25 \%$ & Setuju & Layak \\
\hline 4 & $81,25 \%<x \leq 100 \%$ & Sangat Setuju & Sangat Layak \\
\hline
\end{tabular}

Sumber: Arikunto (2015) 


\section{HASIL DAN PEMBAHASAN}

Pengembangan media pemasaran berbasis website ini dilakukan dengan model waterfall. Pada pelaksanaannya model waterfall dilakukan dengan beberapa tahapan, yang meliputi:

\section{Analisis Kebutuhan}

Kebutuhan sistem tersebut terbagi menjadi beberapa analisis yaitu analisis perangkat keras, analisis perangkat lunak yamg seperti aplikasi apa yang digunakan dalam pengembangan media komunikasi pemasaran, serta analisis kebutuhan konten media komunikasi pemasaran berbasis website seperti informasi isi konten pada media pembelajaran berbasis website.

Perangkat keras berfungsi sebagai alat penunjang dalam melaksanakan penelitian untuk menjalankan perangkat lunak. Pada pengembangan media komunikasi pemasaran perangkat kerasa yang digunakan memiliki spesifikasi processor Intel @ Core TM i5-8250u, spesifikasi RAM 4,00 Gigabytes, spesifikasi hardisk 1 terabytes, dan spesifikasi VGA Intel ${ }^{\circledR}$ UHD Graphics 620.

Perangkat lunak berfungsi sebagai komponen untuk mengembangkan media pemasaran berbasis website. Menurut Sagita (2016) perangkat lunak dapat menunjang saat digunakan dalam mengembangkan media pemasaran berbasis website seperti Notepad++ sebagai text editor pada operating system(OS) windows, Personal Home Page (PHP) sebagai bahasa pemograman untuk mentransfer hasil perancangan menjadi coding, MySQL sebagai basis data, dan apache sebagai web server. Konten media komunikasi pemasaran yaitu terdiri dari; (1) Informasi mengenai teaching factory berisi penjelasan mengenai informasi tentang teaching factory di SMKN 1 Cibadak dan profil jurusan Teknologi Pengolahan Hasil Pertanian ,(2) Informasi produk teaching factory yang ditampilkan mencakup foto produk yang dijual, video proses pembuatan produk, serta deskripsi mengenai produk yang dijual, (3) Infromasi sosial media yang berhubungan dengan sosial media yang ada di SMKN 1 Cibadak, (4) Informasi pemesanan berhubungan dengan tahapan pemesanan yang dapat dilakukan pada website, dan (5) Informasi pengiriman pemesanan berhubungan dengan jenis pengiriman yang dapat dilakukan pada website pemasaran produk teaching factory.

\section{Desain Sistem}

Tahapan pada desain sistem ini merupakan tahapan perancangan dari media pemasaran berbasis website yang disusun dalam bentuk storyboard. Storyboard dipilih karena dapat lebih mudah dalam memvisualisasikan rancangan desain media komunikasi pemasaran. Storybard dalam penelitian ini dibuat menggunakan aplikasi Balsamiq Wireframes untuk membuat mockup website kemudian dibagi menjadi beberapa bagian sesuai dengan tampilan yang dibuat pada layar yang ditampilkan.

\section{Implementasi}

Dalam tahapan ini mengimplementasikan storyboard menjadi sebuah subprogram yang akan dijalankan saat program berjalan. Selanjutnya subprogram dibentuk menjadi sebuah program utama lalu dioperasikan pada Apache server yaitu berupa web browser yang selanjutnya akan dilakukan pengujian. Seluruh tahapan implementasi yang dilakukan dalam pembuatan media pembelajaran ini menggunakan aplikasi perangkat lunak yang dapat digunakan pada perangkat keras yang dimiliki oleh penulis. Perangkat lunak yang digunakan pertama adalah $M y S Q L$, yaitu perangkat lunak untuk membuat dan mengatur data base dari aplikasi yang akan dibuat yaitu website. Selanjutnya dilakukan text editor pada aplikasi Notepad++ untuk menulis apa saja hal-hal yang diperlukan dalam aplikasi ini, setelah itu pembuatan bahasa pemrograman dengan aplikasi PHP Framework Code Igniter. Setelah seluruh program dibentuk, maka akan digabungkan menjadi sebuah program yang akan dioperasikan pada Apache server, yaitu berupa web browser.

Media komunikasi pemasaran yang telah dikembangkan kemudia dilakukan uji coba menggunakan blackbox. Pada pengujian blackbox, media pemasaran telah melalui pengujian dan lolos pengujian tersebut sehingga media pemasaran yang di buat dalam keadaan baik. Pengujian dilakukan oleh pengembang aplikasi yang terlibat dalam pengembangan media pemasaran berbasis website. Pengujian ini menekankan pada sejauh mana fungsionalitas sistem informasi berjalan dengan baik sesuai yang diinginkan oleh pengguna dan pengembang. Terdapat tiga jenis pengujian pada pengujian blacbox yaitu pengujian interface, pengujian fungsi dasar sistem, dan pengujian form handle sistem. 
Program hasil implementasi dalam bentuk web browser yang telah dibuat oleh peneliti dapat dilihat pada Gambar 1 sampai dengan Gambar 22.

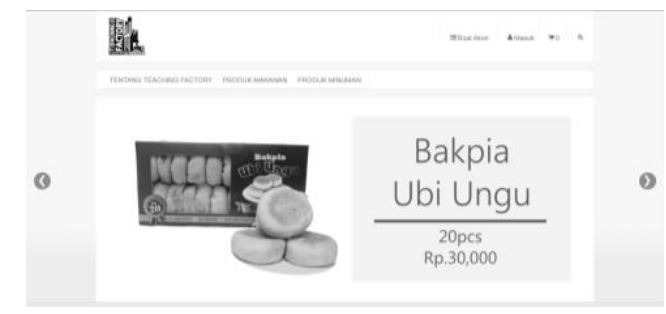

Gambar 1. Tampilan Slide Show pada Halaman Beranda

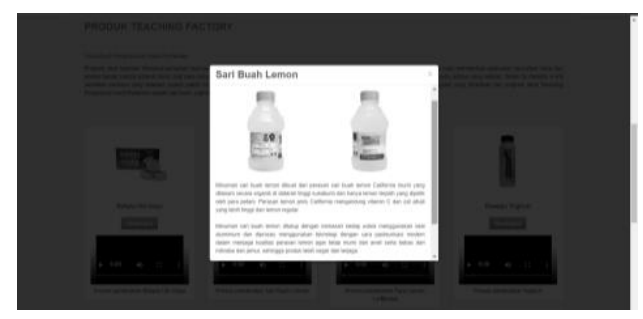

Gambar 3. Tampilan Deskripsi Produk

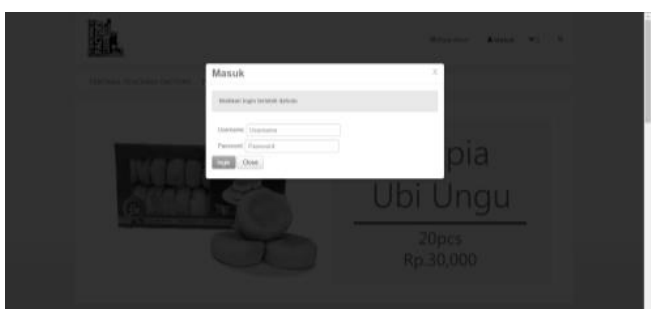

Gambar 5. Tampilan Halaman Masuk

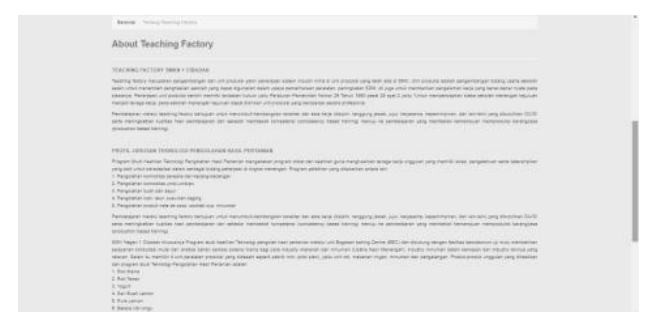

Gambar 7. Tampilan Halaman Tentang Teaching Factory

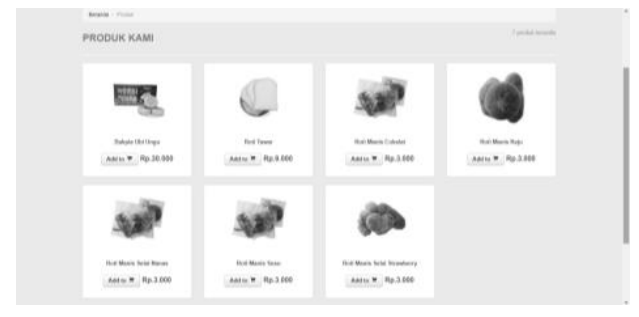

Gambar 9. Tampilan Halaman Produk Makanan

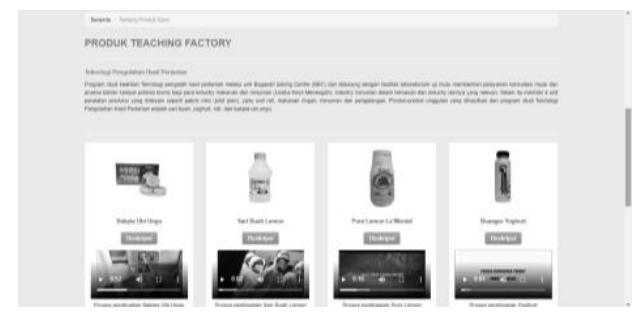

Gambar 2. Tampilan Informasi Produk Teaching Factory

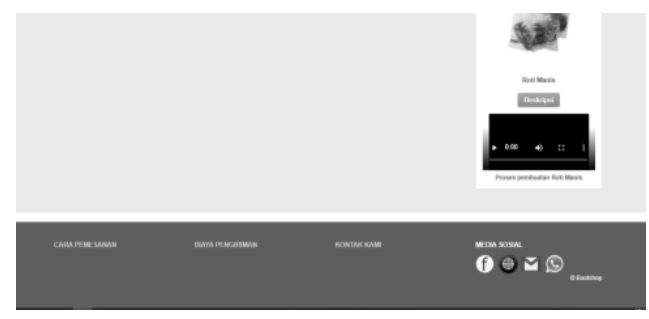

Gambar 4.Tampilan Footer pada Website

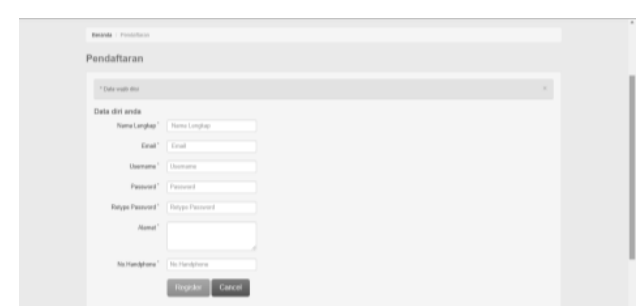

Gambar 6. Tampilan Halaman Pendaftaran

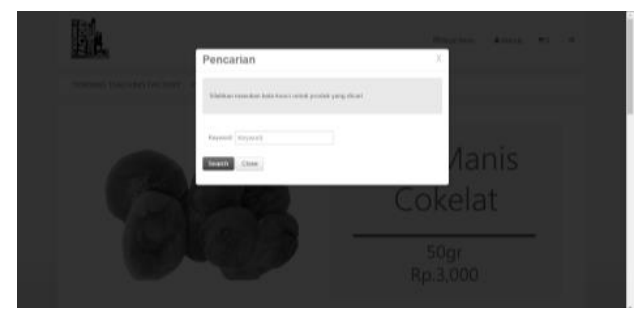

Gambar 8. Tampilan Halaman Pencarian

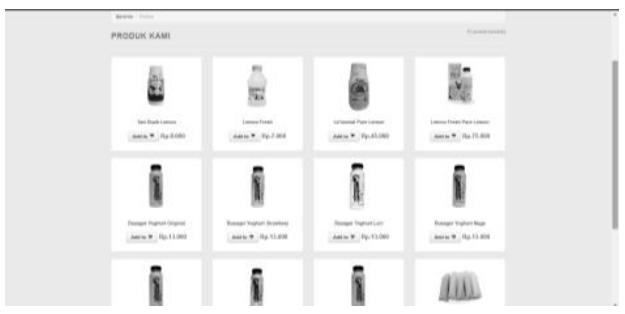

Gambar 10. Tampilan Halaman Produk Minuman 


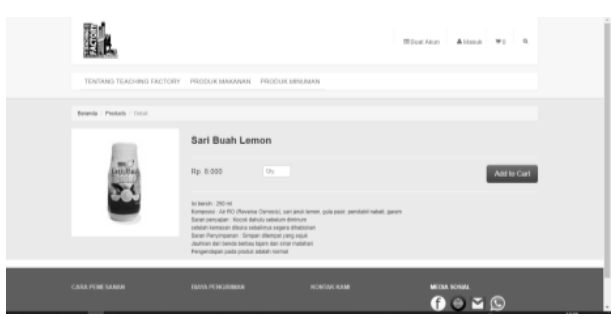

Gambar 11. Tampilan Halaman Keranjang Belanja

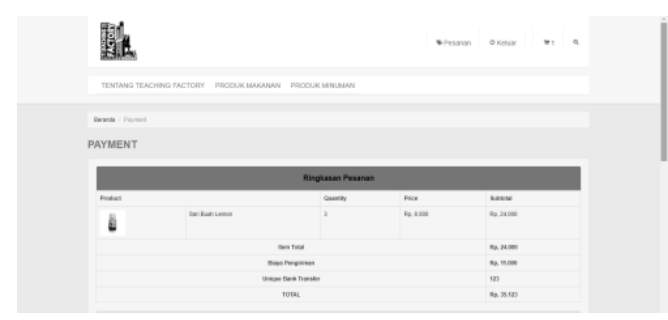

Gambar 13. Tampilan Halaman Pembayaran

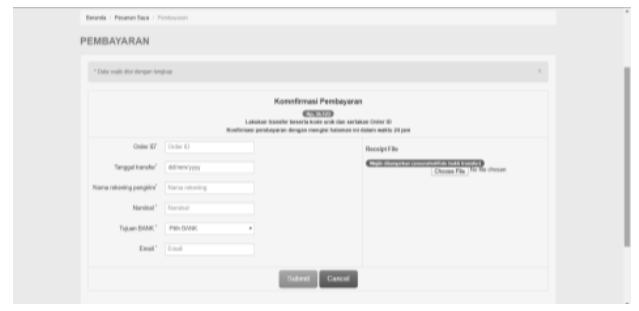

Gambar 15. Tampilan Halaman Konfirmasi Pembayaran

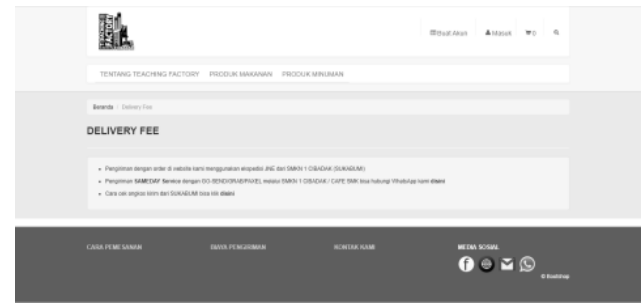

Gambar 17. Tampilan Halaman Biaya Pengiriman

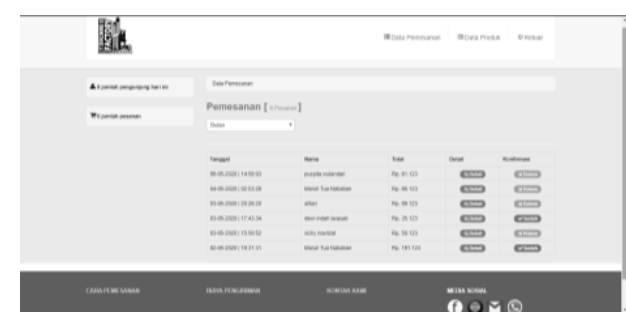

Gambar 19. Tampilan Halaman Data Pemesanan

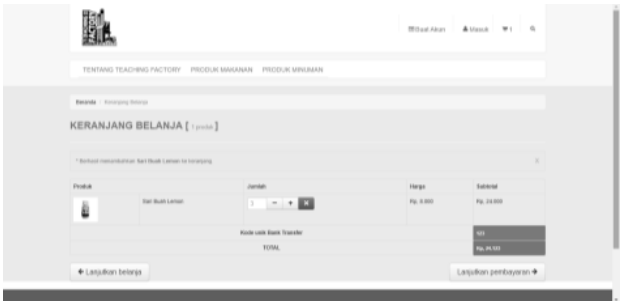

Gambar 12. Tampilan Halaman Jumlah Pesanan di Keranjang Belanja

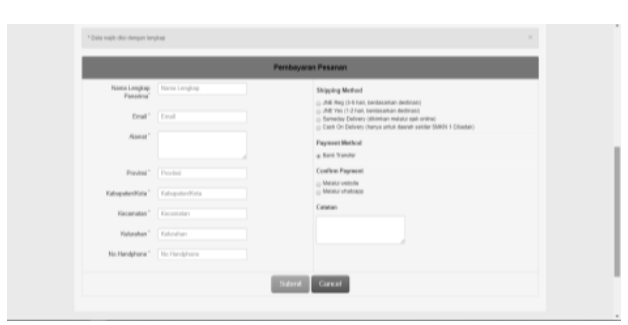

Gambar 14. Tampilan Halaman Pembayaran Pemesanan

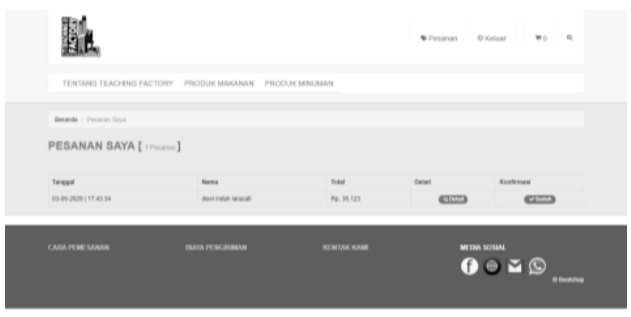

Gambar 16. Tampilan Halaman Pesanan Saya pada Desktop.

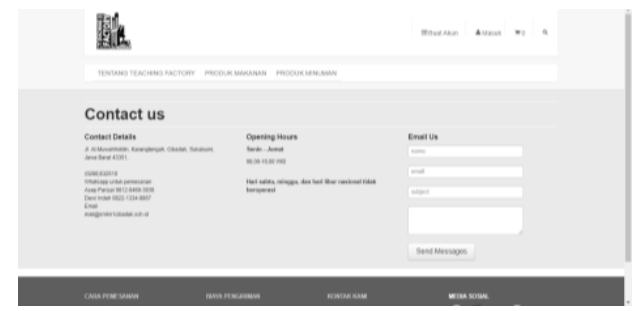

Gambar 18. Tampilan Halaman Kontak dan Media sosial

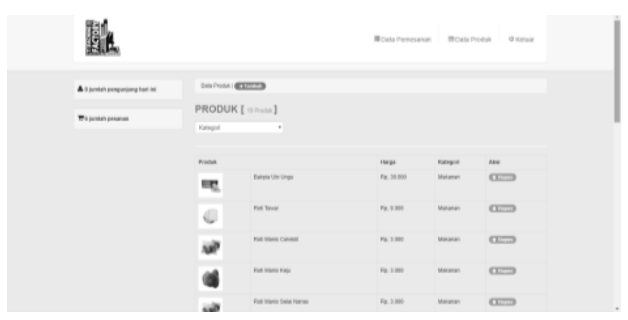

Gambar 20. Tampilan Halaman Data Produk 


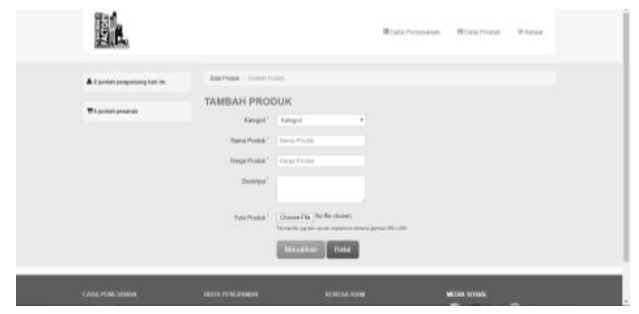

Gambar 21. Tampilan Halaman Tambah Produk

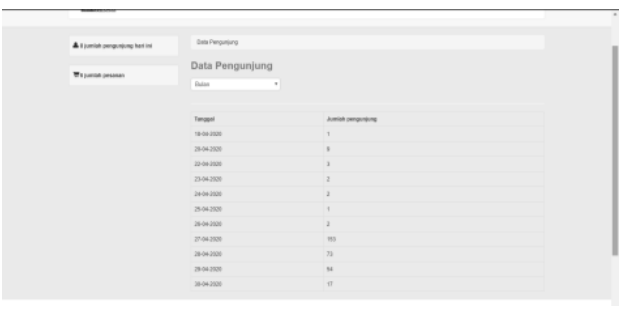

Gambar 22. Tampilan Halaman Jumlah Pengunjung Website

\section{Integrasi dan testing}

\section{a. Hasil Validasi Ahli Media}

Ahli media memberikan penilaian terhadap perangkat lunak (software), teks, navigasi, visual, dan audio. Validasi ahli media didasarkan pada dimensi dan variabel instrumen WebQual (Website Quality) 4.0, hal ini dilakukan untuk menguji aspek kegunaan, aspek fungsional, aspek kualitas informasi, aspek kualitas interaksi pelayanan, dan aspek kepuasan pelanggan.

Berdasarkan hasil validasi oleh ahli media pencapaian yang diperoleh dari yaitu $86,3 \%$, ahli media menyatakan bahwa media komunikasi pemasaran berbasis website yang dikembangkan, Sangat layak untuk diuji cobakan dengan revisi sesuai saran. Grafik kelayakan website hasil validasi ahli media ditunjukan pada Gambar 23

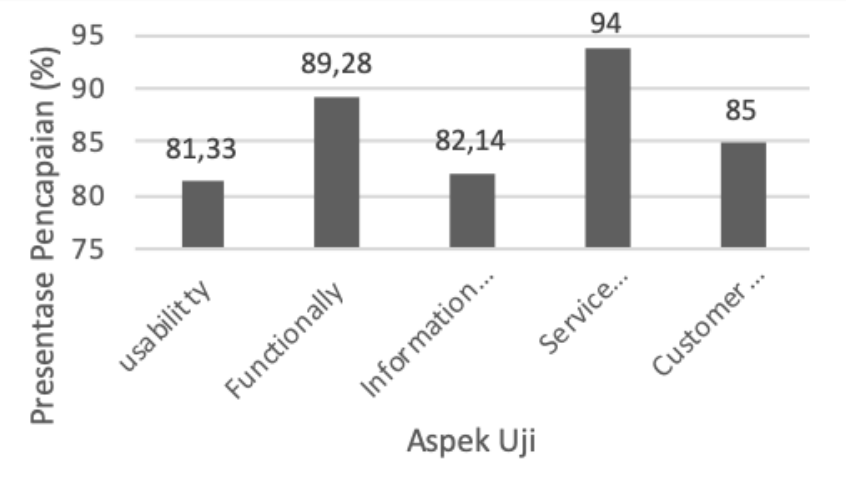

Gambar 23. Hasil Validasi Ahli Media

Pada aspek kegunaan (usability) dinyatakan sangat layak, hal tersebut menujukan bahwa media pemasaran berbasis website memiliki tingkat kemudahan dan kemenarikan yang layak digunakan pengguna. Hal tersebut sesuai dengan penelitian yang dilakukan oleh Karunia (2014) bahwa adanya kecenderungan pengunjung menyetujui pernyataan pada kuesioner yang berarti aplikasi cenderung memiliki penggunaan (usability) yang baik. Hal tersebut menjelaskan bahwa keragaman kepuasan pelanggan dapat dijelaskan oleh aspek usability. Sehingga dapat disimpulkan bahwa kualitas usability yang lebih baik akan meningkatkan kepuasan pelanggan/pengunjung (customer satisfaction).

Pada aspek fungsional (Functionally) dinyatakan sangat layak, hal tersebut menujukan bahwa website memiliki fungsional media yang baik. Hal ini menunjukan bahwa media komunikasi pemasaran memiliki fungsional yang dapat berjalan dengan baik ketika sedang mengoperasikan media komunikasi pemasaran berbasis website. Pada aspek kualitas informasi (information quality) dinyatakan sangat layak, hal ini menunjukan bahwa media memiliki kualitas informasi yang mampu memenuhi kebutuhan kosumen. Hal ini didukung oleh penelitian Karunia (2014) bahwa untuk melakukan pembelian. kualitas informasi (information quality) yang lebih baik akan meningkatkan kepuasan pelanggan/pengunjung (customer satisfaction).

Pada aspek kualitas interaksi (interaction quality) pelayanan dinyatakan sangat layak, hal tersebut menunjukan bahwa website memiliki kualitas interaksi antara pengguna dengan media yang baik, dilihat dari kepercayaan dan empati sehingga menciptakan perasaan emosional yang personal. 
Hal tersebut sesuai dengan penelitian Karunia (2014) bahwa kualitas interaksi (interaction quality) yang lebih baik akan meningkatkan kepuasan pelanggan/pengunjung (customer satisfaction).

Pada aspek kepuasan pelanggan (customer satisfaction) ahli menyatakan bahwa media pemasaran produk teaching factory ini sangat layak, hal ini menunjukan kepuasan pelanggan terhadap penggunaan produk atau ukuran subjektif pengguna terhadap media. Sesuai dengan hasil penelitian Karunia (2014) bahwa terdapat keterkaitan antara kualitas website (Website Quality) dan kepuasan pelanggan (customer satisfaction).

Kualitas website berbanding lurus dengan kepuasan pelanggan terhadap aspek-aspek uji pada penelitian ini. Hasil keseluruhan aspek tersebut dinyatakan layak. Ahli menyatakan bahwa produk layak digunakan uji coba pengguna dengan perbaikan sesuai saran.

\section{b. Hasil Validasi Ahli Pemasaran}

Validasi ahli pemasaran dilakukan untuk mengetahui efektifitas media promosi dengan pendekatan EPIC dan untuk menguji aspek emphaty, aspek persuation, aspek impact, dan aspek communication. Berdasarkan hasil validasi oleh ahli pemasaran diperoleh dari penilaian para ahli pemasaran yaitu $81,23 \%$ "Layak". Oleh karena itu, ahli pemasaran menyatakan bahwa media komunikasi pemasaran berbasis website yang dikembangkan, layak untuk diuji cobakan dengan revisi sesuai saran. Kelayakan website hasil validasi ahli pemasaran ditunjukan pada Gambar 24

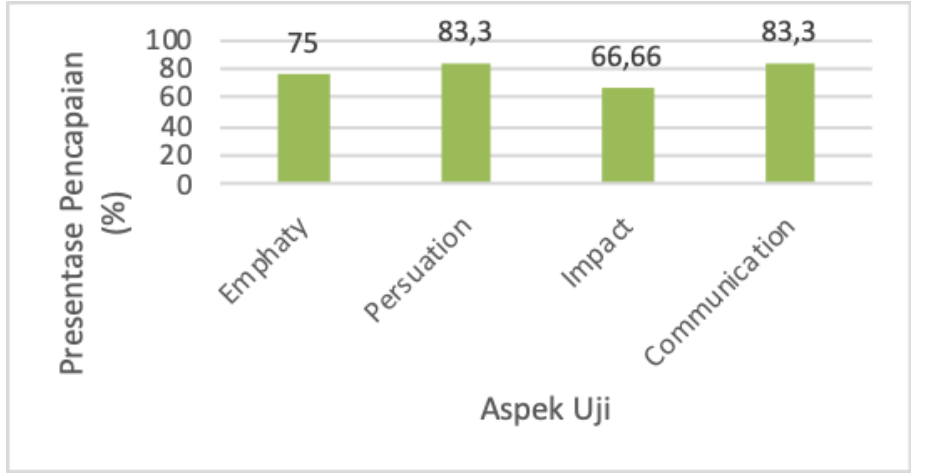

Gambar 24. Hasil Validasi Ahli Pemasaran

Pada aspek emphaty dinyatakan layak, hal ini menunjukan bahwa bentuk media pemasaran ini mampu menarik empati konsumen. Hal ini didukung oleh Yet (2013) terhadap hasil dimensi empati menggambarkan konsumen mampu memahami dan berempati pada produk yang ditawarkan oleh produsen. Pada aspek persuation dinyatakan sangat layak, hal tersebut menunjukan bahwa media pemasaran ini memberikan stimulus, sehingga konsumen memiliki keinginan untuk membeli produk. Merujuk pada penelitian yang dilakukan oleh Riyantoro \& Harmoni (2017) menyatakan bahwa aspek persuasi suatu iklan dinyatakan sangat efektif dalam mempengaruhi pengguna. Hal ini didukung oleh Hisyamsyah (2015) bahwa informasi yang diberikan oleh sebuah media komunikasi mampu meningkatkan atau menguatkan karakter suatu merk, sehingga pelanggan dapat memperoleh pemahaman mangenai dampak promosi terhadap keinginan konsumen untuk membeli suatu produk yang ditawarkan.

Pada aspek impact dinyatakan layak, hal ini menunjukan bahwa merk produk yang ditawarkan mampu bersaing dengan merk produk lain yang serupa dan juga memberi kesan kepada pengguna, mengingat media pemasaran ini khusus untuk produk teaching factory yang pastinya memberi kesan dan berbeda dengan media pemasaran pada umumnya. Hal ini dipekuat dengan pernyataan Riyantoro \& Harmoni (2017) bahwa aspek dampak memperlihatkan bahwa mempromosikan produk melalui iklan. Iklan yang ditampilkan oleh produsen memliki dampak positif yang dapat diterima dengan baik.

Pada aspek communication dinyatakan layak, hal ini menunjukan bahwa media pemasaran ini mampu menyampaikan pesan utama yang mampu diingat oleh konsumen. Merujuk pada penelitian Riyantoro \& Harmoni (2017) bahwa iklan produk mempunyai pesan yang kuat bagi pengguna yang melihat iklan. Selain itu Berdasarkan kerangka sarang lebah media sosial (the 
honeycomb of social media) yang disarankan Kietzman (2011), jejaring sosial dapat didefinisikan dengan menggunakan tujuh hal bangunan fungsional. Tujuh blok bangunan sarang tersebut adalah identitas, percakapan, berbagi, kehadiran, hubungan, reputasi dan kelompok. Setiap jejaring sosial umumnya dibangun dengan fokus nada beberapa atau semua blok. Website menggunakan media komunikasi pendukung facebook, instagram, dan website sekolah sehingga dapat memanfaatkan kelebihan fungsi setiap media sosial yang digunakan pada website ini. Hasil keseluruhan aspek tersebut dinyatakan layak setelah dilakukan revisi sesuai saran dari ahli pemasaran.

\section{Penyebaran Sistem}

Pada tahapan ini dilakukan penyebaran sistem sekaligus dengan pengujian respon pengguna media pemasaran. Pengguna smartphone dan laptop yang terkoneksi jaringan internet di sini dimaksudkan untuk menjadi pengguna (user) website dan juga sebagai responden uji respon pengguna media pemasaran secara keseluruhan sebanyak 97 orang. Dari presentase pencapaian yang diperoleh dari penilaian rata-rata aspek oleh responden yaitu $81 \%$. "Layak", Interpretasi kualifikasi kelayakan dapat dilihat pada Tabel 1.

Hasil dari uji responden dari pengguna media pemasaran berbasis website berrdasarkan perhitungan dengan Moe (Margin of Error) dengan tingkat kesalahan maksimum adalah $10 \%$. Responden yang diambil sebagai sampel merupakan responden yang memenuhi syarat yakni; (1) pernah melakukan pembelanjaan secara online, (2) Pengguna aktif internet, (3) berdomisili di Jawa Barat. Syarat tersebut dibuat peneliti dengan tujuan agar data yang diperoleh mampu menggambarkan tingkat kelayakan media komunikasi pemasaran berbasis website secara objektif. Grafik kelayakan website hasil uji oleh responden ditijau dari aspek information quality, economic feasibility, purchase intention, dan WOM intention dapat dilihat pada Gambar 25.

Information quality (kualitas informasi) mempengaruhi kepercayaan konsumen akan sebuah produk (Kim \& Park, 2013). Pada aspek information quality media pemasaran ini dinyatakan sangat layak, hal tersebut menunjukan bahwa website ini dapat menyajikan data yang dapat dipercaya, bermakna, dan berguna bagi konsumen untuk melakukan pembelian. Meskipun demikian hasil penelian yang dilakukan oleh Aziz (2016) menunjukan bahwa informasi yang up to date, respon keluhan, manfaat infromasi, dan informasi real-time tidak akan mempengaruhi tinggi atau rendahnya kepercayaan pengguna situs jual beli.

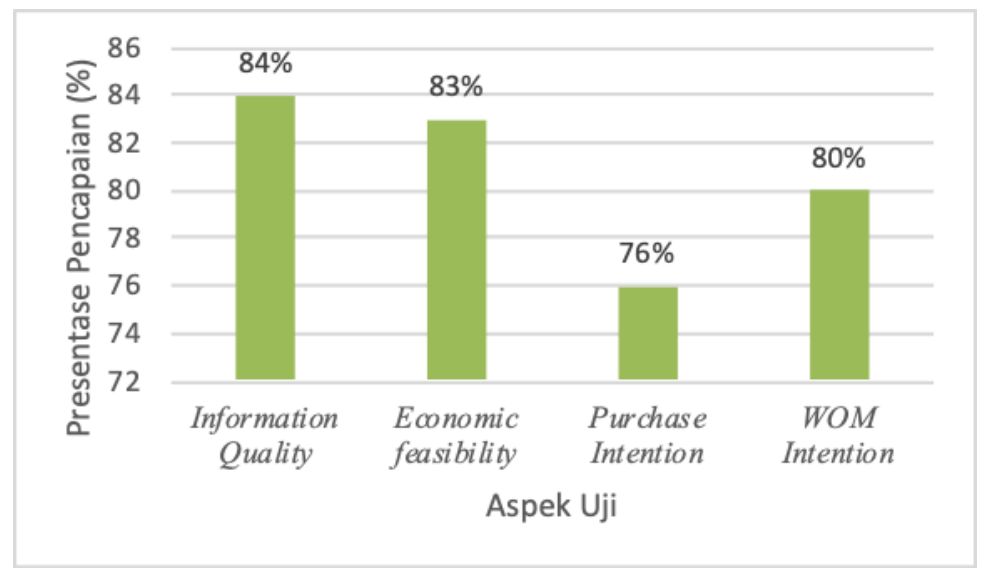

Gambar 25. Hasil Pengujian Respon Pengguna Website

Economic feasibility (kelayakan ekonomi) merujuk pada ekspektasi konsumen terhadap suatu produk yang disediakan e-commerce melalui komunikasi dan informasi yang disediakan (Aziz, 2016). Pada aspek economic feasibility media pemasaran ini dinyatakan sangat layak, hal tersebut menunjukan bahwa website ini memberikan informasi berupa harga produk yang sesuai dengan ekspektasi konsumen, sehingga harga produk mampu bersaing dengan produk lain yang sejenis. Merujuk pada Aziz (2016) bahwa economic feasibility merupakan faktor penentu apakah resiko-resiko 
pembayaran yang dimiliki konsumen akan terjadi atau tidak. Melihat dari sisi karakter e-commerce yang memberikan harga yang jelas memungkinkan konsumen melakukan penelusuran harga pada sebuah barang yang akan dibelinya termasuk untuk melakukan perbandingan harga suatu barang pada tempat lain.

Aspek WOM (Word of Mouth) intention mengukur sejauh mana pembeli akan bertindak atas kemauan atau proses tertentu untuk bertukar informasi positif atau negatif berdasarkan pengalaman langsung dan tidak langsung dengan pembeli lainnya (Aziz, 2016). Pada aspek WOM intention media pemasaran ini dinyatakan layak, hal ini menunjukan bahwa konsumen memiliki potensi untuk bertukar informasi atas pengalaman langsung dengan konsumen lain, setelah menggunakan aplikasi ini, baik dari segi produk maupun informasi terkait website.

Aspek purchase intention mengukur kesediaan konsumen dan bermaksud untuk melakukan transaksi online (Ling, 2011). Pada aspek purchase intention media pemasaran ini dinyatakan layak, hal tersebut menunjukan konsumen memiliki potensi kesediaan dan bermaksud untuk melakukan transaksi online setelah menggunakan aplikasi ini. Beberapa pengunjung website beberapa mencoba melakukan transaksi pada website ini, namun dikarenakan sekolah sedang diliburkan akibat pandemic ini maka transaksi pembelian produk tidak dapat dilakukan. Pada penelitian ini, peneliti menyediakan kolom tanggapan pada kuesioner yang diberikan kepada responden yang memungkinkan responden memberikan tanggapan pribadinya terkait aplikasi pemasaran produk teaching factory, namun tanggapan tersebut tidak bersifat wajib untuk diisi oleh responden.

Secara keseluruhan diperoleh sebayak 97 tanggapan yang disampaikan oleh responden. Terdapat setidaknya tujuh kelompok tanggapan yang ditunjukan oleh responden yakni; (1) tampilan (user interface), (2) Informasi Produk, (3) Penulisan, (4) Jumlah Produk, (5) Fitur, (6) Pernyataan Kepuasan yang ditunjukan pada Gambar 26.

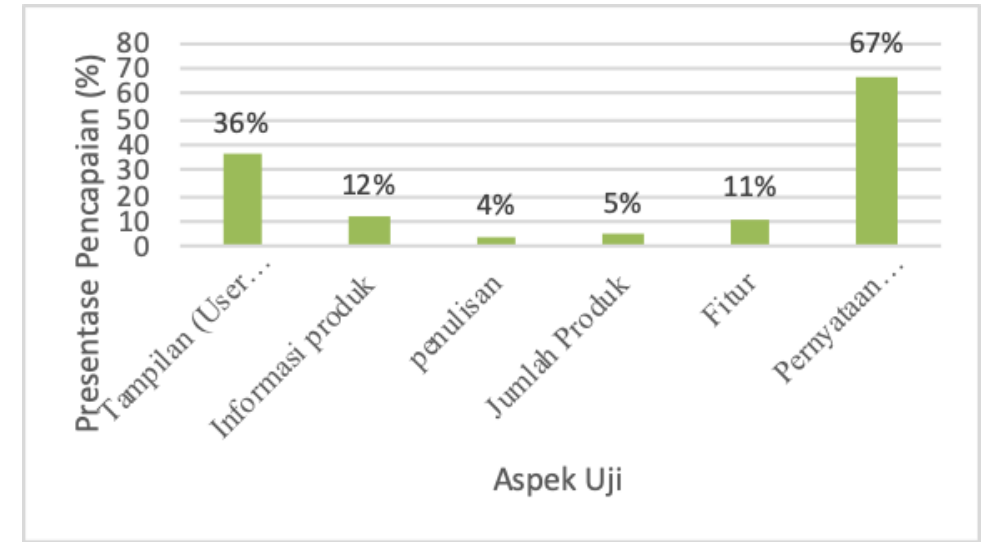

Gambar 25. Hasil Pengujian Respon Pengguna Website

\section{a. Tampilan / User Interface}

Sebanyak 36\% tanggapan responden berisi tanggapan responden yang berhubungan dengan tampilan pada website, tampilan yang dimaksud adalah user interface dan template warna pada website. Perbaikan yang dilakukan yaitu perubahan terhadap user interface atau antarmuka pengguna menjadi desain tampilan yang lebih mudah dalam interaksi dengan pengunjung. Melakukan perubahan pada backround website menjadi warna yang lebih terang karena warna merupakan sensitivitas yang berhubungan dengan indra, dimana warna dapat menarik perhatian, menolak, bahkan bisa mempengaruhi emosi pengunjung website. Warna pada website menimbulkan kesan pertama bagi pengunjung ketika pertama kali mengunjungi website (Suyanto, 2015).

\section{b. Informasi Produk}

Sebanyak $12 \%$ tanggapan responden berisi tanggapan responden terkait dengan informasi produk yang seharusnya diletakan di halaman muka website sehingga penempatannya kurang tepat, karena pengunjung beum tentu mengunjungi halaman tentang produk teaching factory sehingga informasi yang ada tidak sampai kepada pengunjung website. Mengacu dari hasil penelitian Alhasanah (2014) menunjukkan bahwa kegunaan, kualitas informasi dan kualitas interaksi memiliki mengaruh positif terhadap keputusan pembelian. 
Tanggapan responden terhadap informasi produk pada website berisi tanggapan positif, menurut pengunjung detail produk dan informasi yang ada pada website ini sudah cukup lengkap karena mencangkup foto produk, video pembuatan produk, deskripsi mengenai produk, dan keterangan produk yang berisi harga, berat produk, komposisi produk, saran penyajian dan saran penyimpanan produk.

\section{c. Penulisan}

Sebanyak $4 \%$ tanggapan responden berisi tanggapan tentang penulisan. Penulisan yang dimaksud adalah adanya beberapa typo pada penulisan keterangan pada website dan pada penyusunan materi yang ditampilkan. Perbaikan yang dilakukan adalah memperbaiki kata-kata yang typo dan penyusunan kata pada materi yang akan ditampilkan.

\section{d. Jumlah Produk}

Sebanyak 5\% tanggapan responden berisi tanggapan responden terkait jumlah foto produk yang masih kurang. Beberapa rekomendasi yang diberikan oleh responden yakni, penambahan jumlah foto per produk dan penambahan jumlah produk. Berkaitan dengan rekomendasi tersebut peneliti tidak melakukan perbaikan, tanpa adanya penambahan jumlah yang dilakukan oleh kegiatan teaching factory di SMKN 1 Cibadak. Mengacu pada Agasi (2017) menyatakan bahwa mengunggah gambar produk bisa mendatangkan keuntungan, terutama saat melakukan promosi di media sosial, foto berperan penting untuk membuat produk tersebut menarik calon pembeli. Sebuah foto harus bisa mencerminkan keunggulan produk tersebut dan dapat menyampaikan pesan yang ingin dikatakan penjual kepada pembeli dengan jelas.

\section{e. Fitur}

Sebanyak $11 \%$ tanggapan responden berhubugan fitur diantaranya ada video yang tidak dapat diputar, error halaman, dan ada responden yang menyarankan untuk menambahkan live chat pada website, sisanya berpendapat bahwa fitur pada website ini sudah cukup lengkap dan bagus. Untuk video yang tidak bisa diputar bisa saja terkendala karena jaringan internet responden yang kurang baik namun untuk video sudah diperbaiki dan datanya sudah dikompres sehingga datanya sudah tidak terlalu berat ketika di akses.

\section{f. Pernyataan Kepuasan}

Sebanyak 67\% tanggapan responden menyatakan kepuasan responden terhadap media komunikasi pemasaran berbasis website untuk produk teaching factory. Pernyataan kepuasan tersebut diungkapkan melalui penilaian positif dan apresiasi terhadap aplikasi pemasaran ini.

\section{Perawatan}

Pada tahapan ini dilakukan perbaikan yang didapatkan dari masukan positif oleh responden tentang media pemasaran oleh responden dengan pengawasan ahli. Perbaikan yang dilakukan didasari oleh kategori tanggapan responden. Selain melakukan perbaikan pada website peneliti juga melakukan pembayaran hosting website secara rutin untuk setiap bulannya. Pembayaran hosting dapat dilakukan pada my.domaiNesia.com, kemudian memilih perpanjangan stasus hosting website yang kita miliki dan membayarkan sesuai harga yang tertera.

\section{KESIMPULAN}

1. Proses pengembangan media pemasaran berbasis website untuk produk teaching factory SMKN 1 Cibadak terdiri dari; (1) Requirement Analysis, yaitu penentuan kebetuhan aspek perangkat keras dan perangkat lunak (2) System Design, yaitu pembuatan storyboard sebagai acuan pengembangan media pemasaran; (3) Implementation, yaitu penerapan storyboard menjadi sub program dengan menggunakan aplikasi bahasa pemograman PHP dan basis data MySQL serta menggunakan Notepad++ sebagai text editor, sekaligus pengujian black box dan secara keseluruhan media pemasaran lolos uji; (4) Integration and Testing, yaitu penggabungan sub program menjadi suatu program yang utuh dan lakukan validasi ahli media dan ahli pemasaran, selain itu juga di lakukan perbaikan sesuai saran ahli; (5) Deployment of System, yaitu penyebaran program atau aplikasi kepada user sekaligus responden untuk mengetahui respon pengguna media pemasaran; (6) Maintenance, perbaikan yang di lakukan dari saran responden dengan pertimbangan dari ahli. Media pemasaran direvisi sesuai dengan saran yang diberikan, 
sampai menghasilkan produk akhir yang sesuai dengan saran. Hasil produk berupa media pemasaran berbasis website untuk produk teaching factory.

2. Hasil validasi ahli media dan ahli pemasaran terhadap media pemasaran yang dikembangkan memperoleh persetase $86,3 \%$ dan 77,1\% termasuk kedalam kategori "Sangat Layak" untuk ahli media dan "Layak" untuk ahli pemasaran. Kemudian media yang dikembangkan direvisi sesuai dengan saran dari ahli media dan ahli pemasaran. Secara keseluruhan dapat disimpulkan bahwa media pemasaran berbasis website untuk produk teaching factory layak untuk digunakan pada kegiatan marketing promotion.

3. Respon pengguna media pemasaran yang dilakukan oleh responden mendapatkan hasil respon pengguna media pemasaran memperoleh persentase kelayakan dari responden sebesar $81 \%$ termasuk kategori "Layak". Secara keseluruhan diperoleh sebayak 97 tanggapan yang disampaikan oleh responden. Terdapat setidaknya enam kelompok tanggapan yang ditunjukan oleh responden yakni (1) tampilan (user interface), (2) Informasi Produk, (3) Penulisan, (4) Jumlah Produk, (5) Fitur, (6) Pernyataan Kepuasan.

\section{DAFTAR PUSTAKA}

Alhasanah,J. U. (2014). Pengaruh Kegunaan, Kualitas Informasi, dan Kualitas Interaksi Layanan WEB E-Commerce Terhadap Keputusan Pembelian Online.Universitas Brawijaya. Jurnal Administrasi Bisnis. Vol 15. No.2.

Arikunto, S. (2006). Prosedur Penelitian Suatu Pendekatan Praktik. Jakarta: Rineka Cipta.

Aryadhi, I. W., Parmiti, D. P., \& Mahadewi, L. P. P. (2015). Pengembangan E-Learning Dengan Model Waterfall Pada Mata Pelajaran IPA Kelas VIII. Jurnal: EDUTECH Undiksha, Vol 3 No.1 Halaman 5

Aziz M.Z.S. (2016). Pengaruh dari Beragai Karakteristik E-commerce (bukalapak.com) Terhadap Kepercayaan dan Performa Kepercayaan Konsumen di Kota Semaran. (Jurnal). Program Studi Manajemen Fakultas Ekonomi dan Bisnis.

Direktorat Pembinaan SMK. (2017). Tata Kelola Pelaksanaan Teaching factory: Seri Revitalisasi SMK. Jakarta: DirPSMK

Hisyamsyah A.J., Sularso A., \& Suryaningsih I.B. (2015). Analisis Efektifitas Iklan Online Terhadap Minat Beli Konsumen Murah Grosir. Artikel: Urusan Manajemen. Fakultas Ekonomi, Universitas Jember (UNEJ), Jember.

Istanto, H Freddy. 2001. Potensi Kaidah Perancangan situs-web sebagai media komunikasi visual. Surabaya.: Fakultas Seni dan Desain, Vol.3 No.1

Karunia, S. G. (2014). Pengukuran Kualitas Website dengan Menggunakan Metode WebQual . (jurnal). Sekolah Tinggi Manajemen Informatika \& Teknik komputer, Surabaya.

Kietzmann, J. H., Hermkens, K., McCarthy, I. P., \& Silvestre, B. S. (2011). Social media? Get serious! Understanding the functional building blocks of social media. Journal Business horizons, Vol. 54 No.3 Halaman $241-251$

Kim S. \& Park H. (2013). Effects of Various Characteristics of Social Commerce (E-Commerce) on Consumers Trust and Trust Performance. Jurnal: International Journal of Information Management, 6, (5)

Ling K.C, Daud D., Piew T.H., Keoy K.H., \& Hassan P. (2011). Perceived Risk, Perceived Technology, Online Trust for the Online Purchase Intentio in Malaysia. Jurnal: International Journal of Bussiness and Management

Mukaromah S. dan Rosadi D. (2015). Perancangan Aplikasi E-Commerce (Studi Kasus : Distributor Coklat Bandung). Journal : Computech \& Bisnis, Vol.9 No.1. Hal 58-72.

Riyantoro B. \& Harmoni A. (2013). Evektifitas Iklan Melalui Jejaring Sosial sebagai Salah Satu Strategi Pemasaran Keridpik Pedas Maicih. Jurnal: Prosiding: PESAT (Psikologi, Ekonomi, Sastra, Arsitektur \& Te ol 5

Sagita R.A. dan Sugiarto H. (2016) Penerapan knik Sipil) Metode Waterfall Pada Sistem Informasi Penjualan Furniture Berbasis Web. E-Journal AMIK BSI Jakarta. 
Sugiyono. (2011). Metode Penelitian Kuantitatif, Kualitatif dan R\&D. Bandung: Afabeta.

Suyanto, Asep, H. (2009). Step by Step Web Design Theory and Practies. Yogyakarta : Andi

Yet, S. \& Ginting, P. (2013). Analisis Efektivitas Iklan TV Sirup Markisa dengan Pendekatan EPIC Model PT.MAJUJAYA Pohon Pinang Pada Konsumen Swalayan Macam Yogya Yaohan Merak Jingga Medan. Jurnal: Modernisasi, Vol.9 No.1. 